\title{
RESISTANCE TROUGH FAITH INSIDE THE ROMANIAN GULAG. CASE STUDY: THE AIUD RE-EDUCATION
}

\section{Dragoș URSU*}

\begin{abstract}
The complete establishment of communism in 1948 also meant turning Romania into an immense Gulag. For a significant part of those imprisoned, the suffering of detention provided the frame for an identitary repositioning. Faced with torture, cold, and hunger, the political dimension diminishes and the spiritual values are emphasized. Solidarity, resistance, sacrifice, spirituality, and reflection are privileged at the expense of political struggle, combativity, and radicalism. The study aims to investigate a relevant episode of spiritual resistance in the Romanian Gulag, namely the late re-education in the prison of Aiud, during 1959-1964. The re-education had as immediate purposes the dissociation of the imprisoned from their political past, as well as their acceptance of the new political realities. However, through re-education, the regime also pursued the complete annihilation of faith - as a fundament for the prisoners' resistance. The research hypothesis is that in the context of detention, some of the prisoners (re)discovered Christ and reordered their spiritual preoccupations. Thus, prayers (both personal and collective), liturgical life, and spiritual efforts turned the prison cell into a monastery cell, united the prisoners in front of the pressures of the prison administration and created the fundament of resistance through faith against the repressive measures of the administration. The analysis will be structured on two levels: a) how the regime created and imposed the re-education: purposes, methods, results and b) the spiritual resistance of the prisoners: personalities, forms of manifestation, impact. Using documentary sources (file of the former Securitate) and memoirs and literature, the research gains an interdisciplinary dimension, appealing to a diverse methodology: semantic analysis, narrative reconstitution as well as qualitative and
\end{abstract}

*Phd candidate, "Babeș-Bolyai" University (Faculty of History), Cluj-Napoca, Romania. 
quantitative evaluation.

Keywords: communism, repression, political prisoners, spiritual life, martyrdom

Communism represented, first and foremost, the apology of crime as a political instrument. Along with the genocide directed against their political adversaries, communist regimes also proposed a "deicide", desiring to eliminate the main obstacle in the way of building the new man - faith, as a vehicle of identity.

Communist prisons represented the vanguard in the fight against the 'enemies of the people'; they were laboratories of re-education which aimed to annihilate any form of resistance towards the new regime that had been installed using Soviet military support. Apart from its primary role of repressing political convicts, the Romanian Gulag also became a space of ideological (and sometimes religious) confrontation between the regime and the normal Romania.

The communist regime constructed and repressed its adversaries in the name of the ideology that supported its project of social transformation. An important, defining element of the communist ideology was its militant atheism, which proposed the elimination or minimization of the religious dimension and of the role of the Church within society. This explains why, inside the communist prisons, apart from a political resistance, there was also a spiritual resistance which expressed itself under different forms and in different contexts.

The hypothesis of the research is that in the extreme context of detention, some of the prisoners (re)discovered Christ and reassessed their spiritual preoccupations in relation to Him. Thus, prayers (personal and collective), liturgical life and spiritual efforts transformed the prison cell into a monastic cell, uniting the prisoners in face of the administrations' pressures, as well as creating a fundament for resistance through faith in front of the repressive measures of the administration ${ }^{1}$.

${ }^{1}$ Dragoş URSU, "Martirii temniţelor comuniste între identitatea creştină şi cea politică” (The martyrs of the communist prisons between the Christian identity and the political identity), in Mihai HimcinsCHI and Jan NicOlaE (eds.), Eucharist and Martyrdom. From ancient catacombs to the communist prisons, volume I, Alba Iulia, Reîntregirea, 2014, p. 471. 
The spiritual life and resistance through faith within the late reeducation in the Aiud penitentiary represents the subject of the present paper. Religious life was a constant of the communist prisons. Prayers, meditations, biblical readings, services, confessions, and conversions were part of daily prison life, as mentioned by both the prison memoirs and the archival files of the Securitate. Episodes and phenomena of intense spirituality, such as the one focused around Valeriu Gafencu and Ioan Ianolide at Târgu Ocna between 1950 and 1953 represent forms of complete assumption of Christ and martyrdom in His name, in face of the new persecutors of faith.

What particularizes the Aiud re-education (1959-1964) within the landscape of the communist prisons is the massive input invested by the regime in its confrontation with the prisoners. This input also generated vast documentary sources reflecting the entire activity, which are of great use to nowadays historians.

The re-education of the prisoners in the Aiud penitentiary pertains to the (second) large repressive wave of 1958-1959. The process had as an immediate purpose the destruction of the Legionary Movement and the de-solidarization of the imprisoned from their political past, along with their acceptance of the new political realities. However, the regime also attempted, through the same re-education, a complete annihilation of faith as fundament for the prisoners' resistance ${ }^{2}$.

The late re-education in the Aiud penitentiary was the 'creation' of the Aiud Operative Group (GOA), under the direct coordination of the Internal Affairs Ministry's leadership. The GOA officers displayed an intense operative activity, typical to the work of the Securitate (informative notes, reports, informative syntheses, plans of measures, infiltrating agents, operative technique), which supported the 'culturaleducative work' - the euphemistic term used for the re-education. Inherently, the GOA officers generated a large 'documentary production', which gives us the possibility to research the phenomenon thoroughly.

On a methodological plan, it must be mentioned that the files of the Securitate are the faithful image of the ideological perspective in which the regime represented the world. Thus, in the pages of the

\section{${ }^{2}$ Ibidem, p. 480.}


documents, the entire activity of the prisoners gains political tones, of counter-revolutionary activity: the solidarity between prisoners translates into 'legionary support', cultural concerns become 'the profession of the legionary doctrine', the act of conveying internal and international news is tagged as "political plans in view of discharge", while spiritual preoccupations are labelled as 'religious legionary mysticism'.

The ideological 'veil' of the Securitate files poses difficulties in the apprehension of the prison realities, firstly because there is a risk of overrating the political dimension of the prisoners' activity, which was exaggerated by the informative notes and reports. Secondly, attempting to eliminate completely the political identity of the imprisoned brings prejudice to the probity of the analytical effort.

The minimal methodological approaches imposed by a historical analysis thus require an overcoming of the ideological barrier constructed by the language of the documents (as opposed to reality), avoiding universalizing explanations as well as privileging the personal experience of individuals.

Spiritual life in the Aiud prison, as a form of resistance in face of re-education, was the expression of different currents of thought and action belonging to the prisoners. On one hand, an intense spiritual life can be identified around 'mystics' ${ }^{3}$ such as Ioan Ianolide, monk Arsenie Papacioc or Marin Naidim. The mystics benefited from a vast spiritual inheritance $^{4}$ and defined their stance firstly through renouncement to

3 The term 'mystics' refers to the members of the 'Mystics' Group' from the Aiud prison, who initially experienced political detention during the Antonescu period. Gathered around Traian Trifan, they had openly assumed renouncement to the political struggle and a complete experience of life in Christ.

4 The spiritual life of the mystics re-edited the starets-apprentice relationship from the philokalic tradition of the Church. Their activities were structured on four main coordinates: a) biblical, theological and philosophical readings: The Holy Bible, The Paterikon, Saint John Chrysostom, Saint Basil the Great, Saint Gregory Palamas, Saint Ephrem the Syrian, Saint John Damascene, The Lives of the Saints, The Russian Pilgrim, theological manuals - dogmatic theology, mystics, ascetics, biblical archaeology, philosophical works: Berdiaev, Pascal, Bulgakov, Papini, Milton; b) liturgical life: during the Antonescu period, Aiud penitentiary had an orthodox chapel which allowed weekly service of the Holy Liturgy by the priests-prisoners. Services were also held inside the cells. An active role belonged to reverend Vasile Serghie; c) confession of thoughts: both 
political struggle, and secondly through unceasing efforts of practising the Prayer of the Heart. Experiencing the Aiud prison during 1942-1947, followed by the Targu Ocna period (1948-1952) confirmed the superiority of the mystics' essentially spiritual position and projected them into models of sainthood for the other prisoners.

The role of the 'mystics' during the re-education was decisive, since they offered the redeeming solution when confronted with the highly articulated repressive mechanism of the regime. To properly illustrate their activity, I will focus on the important personalities of the group, Ioan Ianolide and father Arsenie Papacioc.

Since the start of the re-education, the officers of the Operative Group identified Ioan Ianolide as one of the leaders of the mystics, as he had a fundamental contribution in defining their position: the centrality of the experience of Christ in the detriment of political activism. In an informative note dated March 1960, the agent mentioned the 'mystical' activity of Ioan Ianolide, who:

"said he doesn't speak like a legionary (...) and that he expresses himself through the fact that the world will not live in peace unless people are the ones to generate love and compassion for one's neighbour, meaning that hatred and feuds must be ended consciously by people themselves. (...) In other words, Ioan Ianolide professes a socalled love for one's neighbour and charity according to the Bible."

The notes and reports dating from the final stages of the reeducation, in the spring of 1964, illustrate Ioan Ianolide as a "great defender of the orthodox faith, (...) mentor and patriarch in the fight of the Church and the nation against the agents of evil, around whom

priests, such as Vasile Serghie and lay men, such as Traian Trifan, had roles of spiritual mentors. Their effort traced, on one hand, a clarification of spiritual dilemmas; on the other hand, they focused on the awareness of sinfulness. d) the Prayer of the Heart: The central aspect which individualized the mystics' group inside the Gulag was their hesychastic effort which aimed the achievement of the unceasing prayer. The catalyst of their search was Valeriu Gafencu, who, guided by the anonymous work the Russian Pilgrim, after lengthy pursuits, managed to acquire the unceasing prayer in extreme life conditions - being isolated in the Zarca (a special, ill-conditions section of the Aiud prison, destined to recalcitrant prisoners).

5 The Archive of the National Council for the Study of the Securitate Archives (ACNSAS), Informative Fund, file 233727, volume 1, p. 159. 
prisoners of every category gather to listen to his helpful word"'.

When released from prison, Ioan Ianolide received what may be called a 'certificate of confession' (of faith), in the unexpected form of the characterization-note made by the penitentiary director, colonel Gheorghe Craciun, who considered Ianolide the creator of 'the mystic group', one who had refused to take part in the re-education "stating that it contravenes his faith"?.

What outlined father ArseniePapacioc's activity, not only in his early years of detention, but also during the late Aiud re-education, were a fully assumed spiritual position ${ }^{8}$ along with a constant Christian mission. In what concerned political struggle, father Arsenie's position was clear, as noted by informant "Andreescu Teodor" in February 1960:

"Legionarism today can no longer sustain its political position - the world has evolved; antisemitism, chauvinistic nationalism and political romanticism cannot be advocated in the same formula as yesterday. To hold on to these old positions means a useless waste of energy and, ultimately, suicide. Or, suicide is contradictory to the Christian dogma. The first commandment, nowadays, is the salvation of the Church, and the Church needs fighters." 9

In his mission, father Arsenie criticizes the militant attitude of legionary activism, advising the imprisoned to direct their hopes towards God, and to surrender their lives to $\mathrm{Christ}^{10}$.

Critical towards the imprisoned legionaries who continued their political combat, Arsenie Papacioc warned against the faithlessness that had grasped some of the prisoners. To him, "communism digs at the fundament of the Church, even here, inside the prison"11. Precisely

\section{${ }^{6}$ Ibidem, p. 186.}

${ }^{7}$ Ibidem, p. 81.

8 Informant "Andreescu Teodor" noted father Arsenie Papacioc's position: "In jail, I promised with Maxim in front of God to dedicate our lives to Him. Poor Maxim couldn't get out of jail, I'm sure that if he had, he would've become a monk as I did, and would have done a good job of it. He should be somewhere here. Also, Ianolide. I've heard them speak that he's still the same; I'd love to see him again. Gafencu was a great soul, but we lost him, he died". ACNSAS, Informative Fund, file 185003, p. 183.

\section{${ }^{9}$ Ibidem.}

${ }^{10}$ Ibidem, p. 179.

${ }^{11}$ Ibidem, p. 182. 
because of this, he prompted those around him to lead a Christian life "which has to bring fruit. Let's help those who stumble around us. The life of retreat and spiritualization is worthless unless it is enlightened by this activity of redeeming man"12.

Along with moral support and spiritual advice, father Arsenie dedicates himself completely to religious life inside the prison cells, by serving daily ${ }^{13}$ (the Matins and the Liturgy) and preaching from the Paterikon, Philokalia and the Rudder (the Pedalion) ${ }^{14}$, thus becoming one of the leaders of the mystics and undergoing an intense operative tracking, as well a restrictive detention regime implemented by the Operative Group.

The spiritual model of the mystics flourished inside the Aiud prison, stimulating the spiritual life of the other prisoners. Some of them understood the model, surpassed the limits of ideological confrontation and assumed completely their Christian identity.

Since the debut of the re-education, the Operative Group

\section{Ibidem.}

13 Informant Andreescu Teodor gives details on the manner of service and the improvised tools for worship: "He easily overcame all difficulties, and improvised simply yet practically all the necessary utensils. Instead of an epitrachelion, which was vital to the Holy Service, he made a loop out of rope; in the morning, he would first bless it, and then put it devotedly around his neck; after finishing the service, he would wrap it around one of his shirt buttons. The stove functions as an altar, the holy cross is made of two tiny sticks kept untied, to avoid suspicions. He carefully sets these on the stove before he starts the morning service, and sets in front of them a thicker wood, so he wouldn't be seen through the aperture of the door cell. The Holy Disk is a flat piece of wood that he carefully wears in the back pocket of his trousers. The water cup is used as chalice, where he puts water instead of wine; he puts aside bread taken from the morning ratio, by cutting according to a specific ritual only from the above part, just like the holy Wafer. He is only missing the Holy Antimension which he cannot improvise, because you need a relic of a martyr. He initially had a piece of relics (St. Mercurius), but he painfully lost them during a search at Jilava Prison. Before 7 o'clock in the morning, when they give the wake-up call, liturgy is already finished and follows the moment of the Eucharist, when each of the people in the room get round to receive a piece of bread and a sip of water. "I carry out the service just as I do at church, and if the Lord sees our need and is willing, this bread and water are even His Body and Blood", in such way the reverend tried to excuse the indigence in which he was forced to perform the service. Since this practice is carried out daily, everyone around now gives a piece from their bread, which is used the next day as Eucharist”. ACNSAS, Informative Fund, file 185003, vol. 3, pp. 194-195.

${ }^{14}$ Ibidem, p. 182. 
documented the activity of the imprisoned priests and theologians, whom they had identified as 'the engines of spiritual life':

"Priests and theology students maintain a bad mentality, as around holidays the priests ask 'who wants to confess' or 'who wants to receive the Eucharist' or that the fasting begins and so on; not all of them, but most of them, I would say the majority." 15

Such a priest is reverend Teodor Bej, whom the Operative Group followed closely. He openly expressed his position, his religiously grounded anti-communist beliefs, urging the other prisoners through an exhortation faithfully noted by an informant:

"Communism is the red beast from the Apocalypse. The deeds of communism have become facts and commanded the power of faith with all their besmirching and bodily and spiritual death of people nowadays. Unless we wake up and start a hostile fight against the rebellious sons of darkness, the destruction will install itself here as well. Let us not leave to our descendants a country with no churches, a house with no icons, and a soul without God." 16

Alongside priests and theologians, models of authentic spiritual life can be discovered among common prisoners. For some of them, the experience of detention represented a time of spiritual conversion, of a plenary experience of Christ. An extensive report of the GOA dated 1959 mentioned and documented spiritual life, along with moral and material solidarity and cultural creations, as fundaments of the prisoners' resistance against the pressures of the regime. Lesser known prisoners, such as Corneliu Hartas ${ }^{17}$, Ioan Hartan and Nicolae Nedelcu ${ }^{18}$,

15 ACNSAS, Documentary Fund, file 13484, vol. 13, p. 189.

${ }^{16}$ Ibidem, p. 74.

${ }^{17}$ In case of Corneliu Hartas, the informant mentions that, "lately, he fell into a religious mania, praying all day long. While he prays, he keeps his legs beneath him and puts a blindfold on his eyes. He states that he is no longer interested in politics, and that he took a higher step, towards holiness, also saying that to him, prison has been a blessing, for it made him find God. (Emphasis added by colonel Craciun himself). He knows the Gospel of John by heart, and states that when he returns home, he will also bring to faith his wife as well". ACNSAS, Documentary fund, file 13482, vol. 2, p. 29.

18 Regarding Nicolae Nedelcu, agent 'Oltet' alerts that: "in discussions he condemns legionaries who aren't faithful, he prays almost the entire day, and says he found contentment within prayer. He knows the Bible and prayers even better than priests. He is 
make a powerful impression through an explicit detachment of their political identity which, along with their daily spiritual efforts, turned their prison cell into a monastery cell.

A tireless confessor and liturgist was father Ioan Iovan. His dignified position during the re-education animated the resistance of the other prisoners and amplified his informative tracking lead by the GOA. Characterized as a 'mystic up to exaggeration' by colonel Craciun ${ }^{19}$, father Iovan performed the liturgy daily in his cell, confessing and giving the Eucharist to other prisoners ${ }^{20}$, while relating about the spiritual movement at Vladimiresti ${ }^{21}$.

Apart from his individual spiritual exercises ${ }^{22}$, father Ioan Iovan had a firm position against the re-education, motivating religiously his fully assumed anti-communist attitude. Informant "Bucur Dumitru" noted:

"Convinced that between communist materialism and Christian spiritualism there cannot be any reconcilement, only the principle that he, himself understands: to entirely follow his duty towards Lord Christ, as the first Christians did, by defending the Church of Jesus. Also, he doesn't fear any disciplinary measure taken against him, not even the death penalty, because he would feel the happiest if he suffered for his faith as much as the holy Christian martyrs did." 23

The same informant, "Bucur Dumitru", characterizes father Ioan Iovan in a note that reflects both the hieromonk's spiritual progress and the intensity of the spiritual life in the Aiud prison at the time of the re-

often requested by other cells to convey through Morse texts from the Bible as well as prayers. Along with cell-mate and priest Hartan Ioan he discusses daily religious problems. Hartan Ioan, at Nedelcu Nicolae's request, performs religious service inside the room, says the prayer before meals and makes antidoron which is shared with the other cells". ACNSAS, Documentary Fund, file 13482, vol. 2, f. 28.

${ }^{19}$ ACNSAS, Informative fund, file 211014, vol. 1, p. 199.

20 "Apart from relating about the miracles at Vladimiresti, the above-mentioned permanently maintains a mystical atmosphere and exalts the religious sentiment by serving mass twice a dat, giving daily Eucharist and confessions, as well as daily conferences having as topics the lives of the saints". ACNSAS, Informative Fund, file 211014, vol. 1, p. 235.

${ }^{21}$ Ibidem, p. 215.

${ }^{22}$ Informants note that on some days "he would pray continuously from 5 a.m. until 10 p.m. standing or on his knees”. ACNSAS, Informative fund, file 211014, vol. 1, p. 214.

${ }^{23}$ Ibidem, f. 235. 
education:

"His mystical influence increases permanently, also due to the way of living adopted by the above-mentioned; he improvised inside his own bed some sort of cell made out of towels, where he sits day and night, saying prayers. He doesn't hold anything against any one, has no conflicts whatsoever, he concedes to everyone, he is full of kindness and mercifulness in anything. At any hour, be it day or night, he is ready to receive another's confession, or to give someone the Eucharist. ${ }^{24}$ Because of these aspects, he is attributed with a holy life, fact which creates him a platform above all the priests in the penitentiary. Even believers of other cults have a feeling of worship towards this man, which is why his word is highly influential among the prisoners." 25

Along with a spiritual life in accordance to the practice of the Church, during the Aiud re-education we can also identify a different kind of resistance, a political one, blending both legionary ideology and Christian notions into a religious synthesis which denotes spiritual confusion. These prisoners, not few, practised what may be called a legionary type of religiousness that combined the cult of heroes with the memorial of the deceased (from the orthodox practise) and intertwined prayers with invocations of the legionary leaders.

A strict delimitation of these religious manifestations in the documents of the Securitate is difficult, because an overlapping often occurs: the 'mystics' also prayed for the founders of the Legionary Movement, while legionaries who invoked the cult of Codreanu ${ }^{26}$ took

24 The role of catalyst of spiritual life that IoanIovan possessed among the prisoners is signalled by informers: "Between the prisoners sentenced to lifelong hard labour, priest Iovan created a solid platform of followers who compete to help him, either to guard the door when he carries out the religious service or when different lectures are being held, or to perform personal services to the priest". ACNSAS, Informative Fund, file 211014, vol. 1, f. 236.

${ }^{25}$ Ibidem.

26 The extreme expression of Codreanu's cult took place during 1946-1947 when prisoner Marin Oprea, from Victor Biris's group, developed a theological conception according to which Corneliu Codreanu was a new Jesus Christ who came to earth a second time in order to redeem the Romanian nation and the other nations as well. The imprisoned priests had a firm attitude against this heresy, particularly the reverend Nicolae Grebenea, but it was pointless. Victor Biris himself, acknowledging the side slip, sent a letter to Oprea Marin in the Suceava prison, in which he explained the heresy and dissociated himself 
part in prayers along with the other prisoners.

Differentiation is only possible through nuance and accent. To the mystics, spiritual exercise is their main preoccupation, as they follow spiritual fulfilment according to the practice of the Church. To the others, expressing faith is a rather exterior act, merely an element of their legionary religiousness ${ }^{27}$.

In general, the GOA assimilates these two practices by overlapping. The cult of Codreanu is considered a religious manifestation, while religious services or the Prayer of the Heart are deemed as legionary propaganda. Therefore it is very difficult to dissociate, for instance, from a report which scarcely mentions that prisoners have 'religious preoccupations', which of these are typical to the Christian faith and what is typical to legionary religiosity.

These multiple aspects of religious life were present during the re-education as well. Paradoxically, the re-education represented a moment of deep tensions and interior transformations for the prisoners. In the case of the mystics, the re-education amplified their detachment from the legionary movement, and emphasized their Christian transfiguration of suffering, confirming faith as a fundament of complete resistance to communism.

In the case of other spiritually anguished prisoners, for whom political beliefs continued to overlap with the religious ones, the reeducation became a moment of clarification, of awareness towards the uselessness of political struggle, and a deep re-evaluation of their Christian identity.

A representative case for this category is Ilie Niculescu. He was a former professor at the Commercial Academy, commander of the

from this attitude. On his death bed, Oprea Marin asks priest Ioan Florea for confession and communion. The reverend explains to him it is impossible, unless he abandons his heresy. Oprea refuses and dies in 1947. His tragic ending prompted his followers to renounce propagating the heresy. ACNSAS, Documentary fund, file 13485, vol. 10, p. 371.

${ }^{27}$ Dragoș URSU, “Reeducare și viață cotidiană în penitenciarul Aiud”, in Între transformare și adaptare. Avataruri ale cotidianului în regimul comunist din România, Annuary of the Institute for the Investigation of Communist Crimes and Memory of the Romanian Exile (IICCMER), Volume VIII, Polirom, 2013, p. 117. 
'Razleti' ${ }^{28}$ during the legionary government and an active participant in the January 1941 events. Ilie Niculescu continued his political activity during detention as well, being the first chief $^{29}$ of the legionaries in the Aiud prison during the Antonescu government.

The re-education process forced the legionaries, especially the leaders, to reflect upon their errors and upon the Legionary Movement ${ }^{30}$. Their answers and repositionings were diverse, varying from prisoners who 'surrendered', thus condemning their political past, to those who admitted to their mistakes but repositioned themselves identitarily, interpreting their own past in a spiritual key.

Such is the case of Ilie Niculescu. In the aftermath of the shock caused by the (self)unmasking of Victor Biris, Niculescu asserted clearly that he would completely and categorically renounce any present or future (political) activity ${ }^{31}$.

The retreat from politics to a Christian positioning was not well received by the GOA, who tried to determine Niculescu to abandon his newly found stance. The 'clarifying' roles were given to Stefan Delavale, Nicolae Nitulescu and Valeriu Anania ${ }^{32}$.

Even though he had been sent by colonel Craciun at the suggestion of agent 'Graur' 33 in order to confute Niculescu's 'legionary mysticism', Anania's contribution was in fact a positive one. He theologically ${ }^{34}$ argued the mistakes of legionarism, explaining the major

${ }^{28}$ The 'Razleti' detachment comprised legionary intellectuals.

${ }^{29}$ ACNSAS, Informative fund, file 375778, vol. 1, p. 271.

30 This process was noted and inventoried by George Enache, "Biserică, societate, naţiune, stat în România interbelică. Biserica Ortodoxă Română şi ispita totalitară de dreapta", in Revista Teologică, no. 2/2012, p. 300.

${ }^{31}$ ACNSAS, Informative fund, file 375778, vol. 5, f. 98.

${ }^{32}$ Ibidem, f. 81.

33 "Having been brought into the room a month ago at the request of the undersigned, prisoner V. Anania fulfilled the task which I had thoroughly shared to him since the first days of the club's activity: to reveal to Ilie Niculescu the contradictions and confusions existent in the legionary ideology, as well as the inconsistencies of the legionary actions, seen from the point of view of the so-called Christian nature of the legionary movement. I considered this absolutely necessary considering Niculescu's anchoring particularly in this religiosity. ACNSAS, Informative Fund, file 375778, vol. 5, p. 124.

${ }^{34}$ In his discussion with Niculescu, Anania insists on the flagrant incompatibility between the Christian principles proclaimed by the legionary movement and their crimes; he insists on the confusion between the Christian identity and the legionary identity, on using religious 
difference between the 'faithless' and the 'faithful' ${ }^{35}$.

The pressure of the re-education, the awareness on the political failure of the Legionary Movement, the disappointment caused by the 'surrendering' of the legionary leaders, along with the contact with the theologians who confirmed his spiritual searches determined Ilie Niculescu to clear away the ideological layer and to assume the values of faith.

His position, made public during the club sessions, reflects the conclusions that Ilie Niculescu reached after long-term inner turmoils, having experienced them for more than twenty years of political detention. Having been a legionary leader both in freedom and in confinement, Ilie Niculescu's declaration stands out through its accurate inventory of the failure of the ideological-religious confusions that had marked the carceral biographies of many prisoners ${ }^{36}$.

symbols (such as the Archangel Michael) for political purposes". ACNSAS, Informative fund, file 375778, vol. 5, pp. 98-106).

35 "Niculescu was a man of great finesse and inner delicacy; he was mannered, elegant in his gestures and vocabulary. Niculescu wanted to know much more about the true rapports between Christianity and the legionary movement, a greatly controversial topic in all the political and church circles. He was only appeased and enlightened by the distinction I offered him between the notions of "faithful" (bine-credincios, rom.) and "faithless" (raucredincios, rom.). Apart from this, I had long and interesting dialogues with him, about philosophy, literature and art. We connected and remained friends". BARTOLOMEU ANANIA, Corupția spirituală: texte social-teologice (edition by Radu Preda and Bogdan Ivanov), Cluj Napoca, Eikon, 2011, p. 329.

36 "For decades we have been feeding ourselves with the consciousness that we are more than just a political party, and even more than a school: that we are a religion and that we assigned our ideology and combat with all the attributes of absolute truths. (...) We must understand now that not the community of the nation, but that of the Church operates the salvation of man, and that the pretention of our legionary messiahship was nothing else than an attempt to replace the soteriological function of the Church. (...) At least now we must admit that this false vision on Christianity gave birth to the ego of considering ourselves modern crusaders. We have not only failed to promote a direction of highly spiritual living, as we intended to, but we also found our wretched history to have been pervaded by a morbid current within which numerous acts of violence took place, going as far as murder. Today I must confess that the amalgamation of the religious and the political levels led, in the end, to the sacrifice of the former. That we made an enormous disservice to the doctrinaire integrity of each of us and, even though we have been faithful, we weren't always right, but often wrong. In what concerns me, I now realize all this and declare I no longer intend to turn my faith into an instrument of political combat". ACNSAS, Informative fund, file 375778, vol. 1, p. 294 (retro-verso). 


\section{Conclusions}

In its repressive, ideologically-driven actions, the communist regime instrumentalized carceral realities, with the purpose of politically justifying and judicially framing the annihilation of any forms of resistance on behalf of the prisoners.

Detachment from the political struggles and the assumption of the Christian identity by some of the prisoners forced the Securitate to reshape its repressive policies. Having initially assimilated religious life to legionary activity, the Aiud Operative Group admits, in the end, to the superiority of the mystics' position, labelling them as the most dangerous prisoners out of the recalcitrant ones.

Paradoxically, the Securitate did not deem the most dangerous to be the fanatic prisoners "who state they still remain legionaries", since their attitude remained in the political sphere, the material one - a space in which the regime was all-powerful.

On the contrary, the regime was unable to control those prisoners for whom the political struggle was obsolete, and Christian faith was completely assumed. They did not know how these men thought; they did not possess the necessary instruments to control such kind of attitude. These men were the complete conquerors of communism and ideologies of any kind.

\section{References}

1. The Archive of the National Council for the Study of the Securitate Archives (ANCSSA), Informative funds, files 223727, 185003, 211014, 375778 and Documentary funds, files 13482, 13484, 13485;

2. Bartolomeu ANANiA, Coruptia spirituală: texte social-teologice, (edition by Radu Preda and Bogdan Ivanov), Cluj Napoca, Eikon, 2011;

3. ENACHE, George, "Biserică, societate, naţiune, stat în România interbelică. Biserica Ortodoxă Română și ispita totalitară de dreapta", in Revista Teologică, no. 2/2012;

4. URSU, Dragoş, "Martirii temniţ̧elor comuniste între identitatea creştină şi cea politică" (The martyrs of the communist prisons between the Christian identity and the political identity), in Mihai HIMCINSCHI and 
ARS LITURGICA. From the Image of Glory to the Images of the Idols of Modernity

Jan NiCOLAE (ed.), Eucharist and Martyrdom. From ancient catacombs to the communist prisons, vol. I, Alba Iulia, Reîntregirea, 2014;

5. URSU, Dragoș, "Reeducare şi viață cotidiană în penitenciarul Aiud", in Intre transformare și adaptare. Avataruri ale cotidianului în regimul comunist din România, Annuary of the Institute for the Investigation of Communist Crimes and Memory of the Romanian Exile (IICCMER), Volume VIII, Polirom, 2013. 